\title{
Teacher’s Assessment for Students’ Learning in Classroom Using Lesson Study and Open Approach
}

\author{
Sirirat Chaona, Narumol Inprasitha \\ Faculty of Education, Khon Kaen University, Khon Kaen, Thailand \\ Email: sirirat_chaona@hotmail.com
}

Received September $25^{\text {th }}$, 2013; revised October 26 ${ }^{\text {th }}$, 2013; accepted November $23^{\text {rd }}, 2013$

\begin{abstract}
Copyright (c) 2013 Sirirat Chaona, Narumol Inprasitha. This is an open access article distributed under the Creative Commons Attribution License, which permits unrestricted use, distribution, and reproduction in any medium, provided the original work is properly cited. In accordance of the Creative Commons Attribution License all Copyrights (C) 2013 are reserved for SCIRP and the owner of the intellectual property Sirirat Chaona, Narumol Inprasitha. All Copyright (c) 2013 are guarded by law and by SCIRP as a guardian.
\end{abstract}

\begin{abstract}
Previous procrastination research has provided considerable support for procrastination as a failure of self-regulation. However, procrastination has rarely been examined in relation to models of self-regulated learning. The purpose of this study was to understand the motives and reasons for academic procrastination from a self-regulated learning perspective. The current study employed a mixed-methods design in which participants completed several survey instruments of academic procrastination, self-regulation, and academic motivation and participated in semi-structured interviews. Findings indicated that academic procrastination was related to poor self-regulatory skills and defensive behaviors including self-handicapping strategies. Only limited support for students' demonstration of procrastination as an adaptive behavior (or, active procrastination) was also indicated. Limitations and implications for future research are discussed.
\end{abstract}

Keywords: Assessment for Learning; Open Approach; Lesson Study

\section{Introduction}

National Education Act 1999 (the Revised Issue, 2002) mentioned that the school had to assess students by considering their development and behavior, learning behavior observation, activity participation and testing in aligned with instructional process based on appropriateness with each level as well as Educational Model. The teacher played an important role in evaluating the students' progress by various techniques appropriately with nature of subject, and students' developmental level (Ministry of Education, 2008). But, the assessment in Thailand still emphasizes on learning achievement, especially the achievement obtaining from testing (Inprasitha, 2003). In addition, Chiengkoon (2006) stated that teachers could not promote the students' learning because the teachers have had traditional style of teaching as lecturing focused on content as well as testing for memorization. Since the assessment by test did not measure students' real condition, and could not assess both of product and process which the students had real practice. Moreover, it could not indicate development clearly. The real achievement was not assessed only using the test. Leahy et al. (2005) stated that the information from testing was difficult to be utilized according to 2 reasons: 1 ) the short duration of time in classifying each standard or skill in marking period. So, testing was performed only to investigate the overall learning achievement rather than to find the cause of students' specific weak point, and 2) the existing information was too late to be utilized, to use the findings in general improvement such as repetition of teaching, or extending more time in learning unit, or specify the teacher who succeeded in teaching that unit. If the academic gave an importance to the evaluation for instructional development by focusing on details, it would lead to the real changes in learning and teaching.

The assessment for developing the students' learning, Robinson \& Bartlett (1993) stated that it was in context of instructional management as the process in trying to understand the students' activity participation. It was more than testing since it should be continuously and regularly performed in order to see the students' understanding in the process, interaction, and application. It was not the last step of instructional activity. But, it was the starting point for enhancing the students' learning. It was supported by Miyauchi (2010) that the children's assessment while they were participating in classroom activity was the most necessary thing to be done. In order to accomplish curriculum objective, teacher should collect data of students' changes and progress of thought and comprehension. White (2007) suggested that assessment should be seen as a process for gathering evidence and making judgment about students needs strengths, abilities and achievements. So, when the assessment was spoken, the process should be emphasized rather than produced. In classroom using the assessment for supporting one's learning, the teacher should adjust teaching continuously in order to see the students' changes (Leahy et al., 2005). Black \& William (1998) concluded the research studies regarding to the occurrences in class as follows: 1) to set the problem as guidelines for students to use their skill as well as apply their approach, 2) to provide opportunity for students to communicate what they had learned by drawing, acting, role playing, concept mapping, 
and writing, 3) to observe by listening to the students while they were explaining and reasoning, 4) to set question by using open-ended problem situation as the phrase inviting the students to explore their own approach and reason, and 5) to discuss the words or techniques used by the students.

Inprasitha $(2003,2004)$ recommended a guideline that for instructional activity management to enhance the students to have learning process, it was necessary to use the innovation in learning and teaching. For instance, open-ended problem which was special being different from other kinds of mathematical problem since it included broader meaning than general exercise in Thailand. It was also used in teaching approach by the Center for Research in Mathematics Education (CRME) in studying the Japanese Lesson Study to be used in Thailand since 2002. Inprasitha (2010) brought the Open Approach to be used as a teaching method focusing on problem solving in the process of Lesson Study. The 4 phases are consisted of 1) Posing open-ended problem, 2) Students' self-learning, 3) Whole class discussion and comparison, and 4) Summarization of students' mathematical ideas emerged in the classroom. These 4 phases were included in 3 steps of Lesson Study as: 1) collaboratively planning, 2) collaboratively observation, and 3) collaboratively reflection. Therefore, in viewpoint of students' assessment in mathematics class, major issues could be concluded that the evaluation for developing and supporting students' learning should be emphasized. Specifically, for the assessment in mathematics class using the Lesson Study and Open Approach, it was necessary to explain evaluation technique for students' learning, since the innovation was used by teachers, as context enhancing the learning in both of teacher and students (Inprasitha, 2010).

\section{Research Methodology}

The qualitative research methodology was administered in this research. Data were presented by descriptive analysis in context of schools under the project of Mathematics Teaching Professional Development through the Lesson Study and Open Approach. The objective was to explore the teacher's assessed for students' learning in classroom using Lesson Study and Open Approach. The Lesson Study was implemented based on Inprasitha's (2010) including 3 phases of implementation.

In this case, Lesson Study group comprised of a mathematics teacher and an internship mathematics student. The first phase of lesson study: collaboratively planning which was the phase that the teacher and internship mathematics student in school collaborated in planning the lesson together, Phase 2: collaboratively observation. In this phase an internship mathematics student as a teacher that teaching in the lesson plan and teacher was observer. Activities in the classroom were video and audio-recorded for analysis purposes. The group had planned a 50-minute lesson to teach on the topic addition (increase) in first grade mathematics class. Phase 3: collaboratively reflection, mathematics teacher and internship mathematics student reflected about the lesson and student learning.

The researcher was a graduate student in Mathematics Education program, Faculty of Education, Khon Kaen University, used to be the first cohort of 5-year in Mathematics Education Program, Faculty of Education, Khon Kaen University. In 2008, the researcher practiced teaching in school for one year, in the school using Lesson Study and Open Approach, had experience in learning organizational planning with the Lesson
Study Team, and used the plan in classroom, participated in reflection after instructional management. After graduating in Bachelor's degree, the researcher furthered her studying in Master's Degree in Mathematics Education Program, Faculty of Education, Khon Kaen University, and had experience in working as well as learning in the Project of Professional Development based on Lesson Study and Open Approach as a researcher in the Lesson Study team.

Target Group was an internship mathematics student, who had teaching practices at Ku-Kam-Pittayasan school, KhonKaen province as the schools under the Project of Professional Development based on Lesson Study and Open Approach conducted by the Center for Research in Mathematics Education, Faculty of Education, Khon Kaen University since 2006, respectively.

Delimitation of the study, in this research, the researcher determined boundary of what to be explored as the assessment method used by internship mathematics student in assessing the students in class administering the Open Approach and Lesson Study.

\section{Results}

Activities: Teacher posed the open-ended problem by show Figure 1 and asked the students to notice and survey a number of fish and provided students to tell story about the fishes in the picture.

In context of Lesson Study and Open Approach, the internship mathematics students used assessment method for their students' learning by considering 4 steps of the Open Approach as guidelines for teaching, as follows:

\section{Step 1: Posing the open-ended problem}

When teacher set task as an open-ended problem to the students, she waste time for students as investigate material and understand situation that teacher post in the classroom. And she provided opportunity for students to communicate about problem and their learning. Teacher assessments were as follows:

1) determine the started problem situation in the guidelines for students to use their approaches.

2) provide opportunity for students to communicate their learning.

3) observe or listen to the students' posing or presentation.

4) set the questions for students to explored their ideas or reasons.

\section{Step 2: Students’ self-learning.}

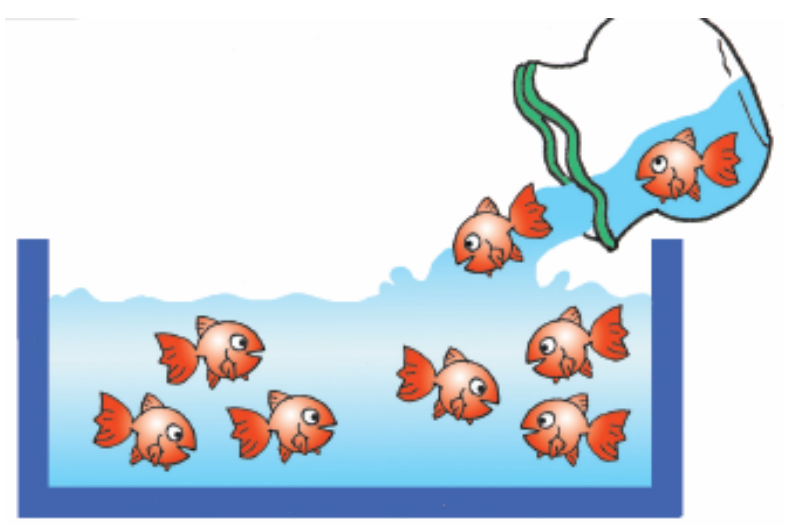

Figure 1.

Addition (increase) Hitotsumatsu (2005: p. 40). 


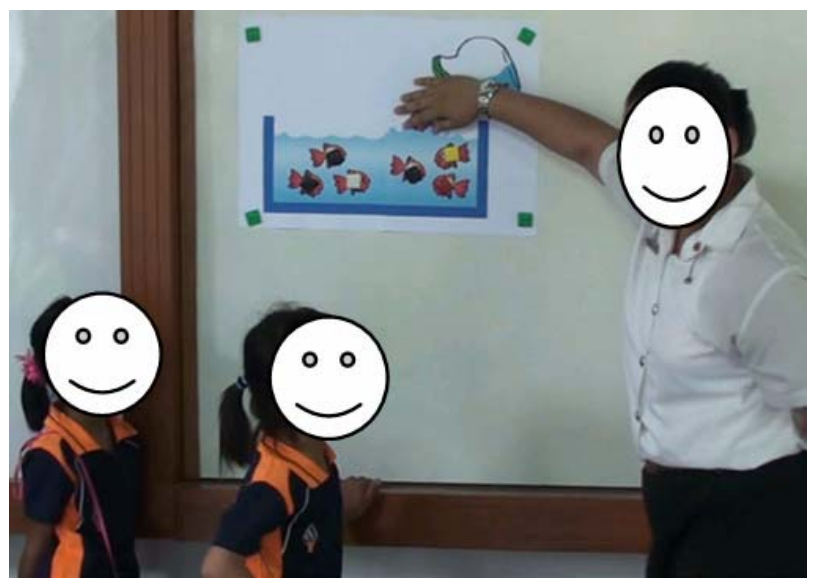

Figure 2.

Teacher posed the open-ended problem.

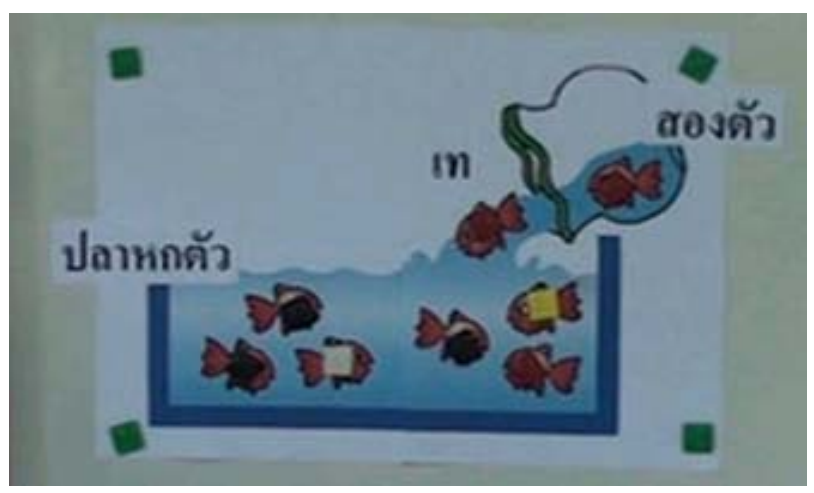

Figure 3.

Students' idea about problem situation.

Teacher gave the task for group work. Teacher assessments were as follows:

1) provide opportunity for students to communicate their learning by drawing picture, acting, role playing, concept mapping, and writing.

2) evaluate by observation including listening to what the students explained their work, task and reasons.

\section{Step 3: Whole class discussion and comparison}

In this step when the student had already group work, teacher asked them to present the idea or reason about the task to whole class for learning together. Teacher assessments were as follows:

1) provide opportunity for students to communicate their learning by drawing picture, acting, role playing, concept mapping, and writing.

2) observed by listening to what the students explained their work task and reasons.

3) ask question by using the open-ended question as the phrases persuading the students to explore the ideas or reasons.

4) discuss the wordings or techniques used by students.

Step 4: Summarization through connecting students' mathematical ideas emerged in the classroom.

In this step after in the classroom discussion have many idea from the students teacher asked student to summarize the lesson about what they have to learn. Teacher assessments were as follows:

1) observe by listening to what the students explained their

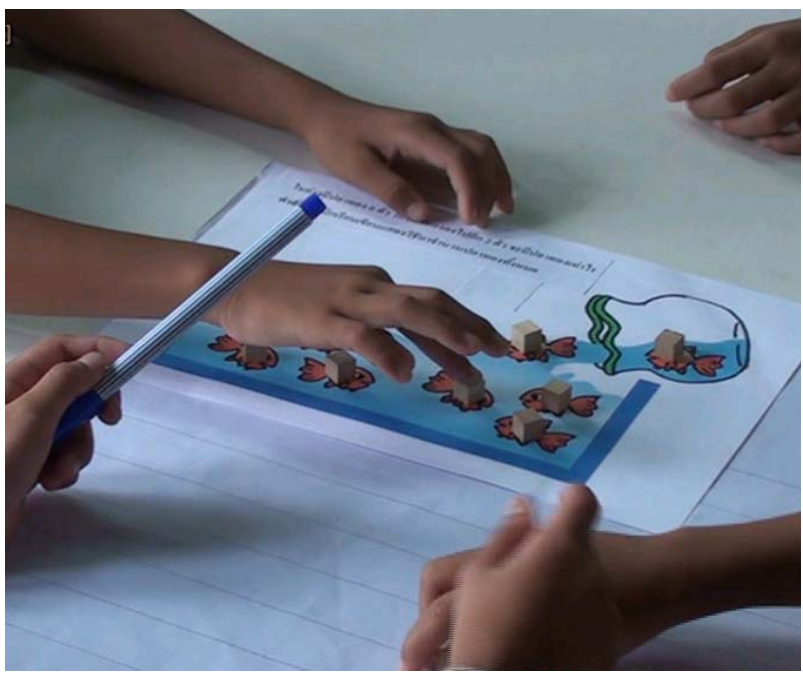

Figure 4.

Students communicated idea in small group.

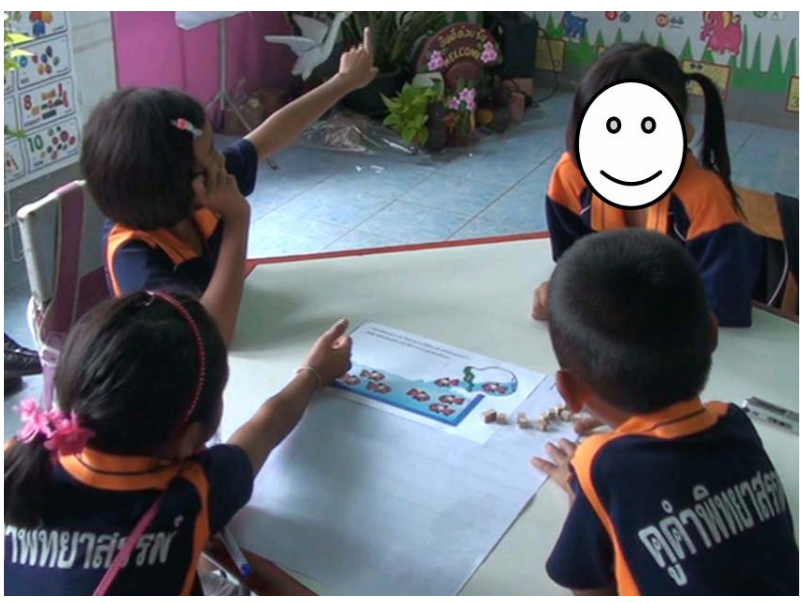

Figure 5.

Students explain their work and reasons in small group.

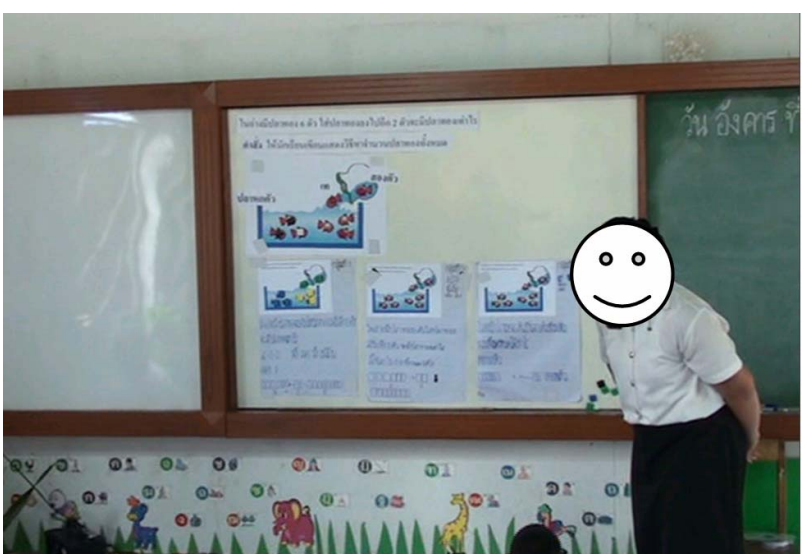

Figure 6.

Discussing words and how students are used.

work task and reasons.

2) ask question by using the open-ended question as the phrases persuading the students to explore the ideas or reasons. 


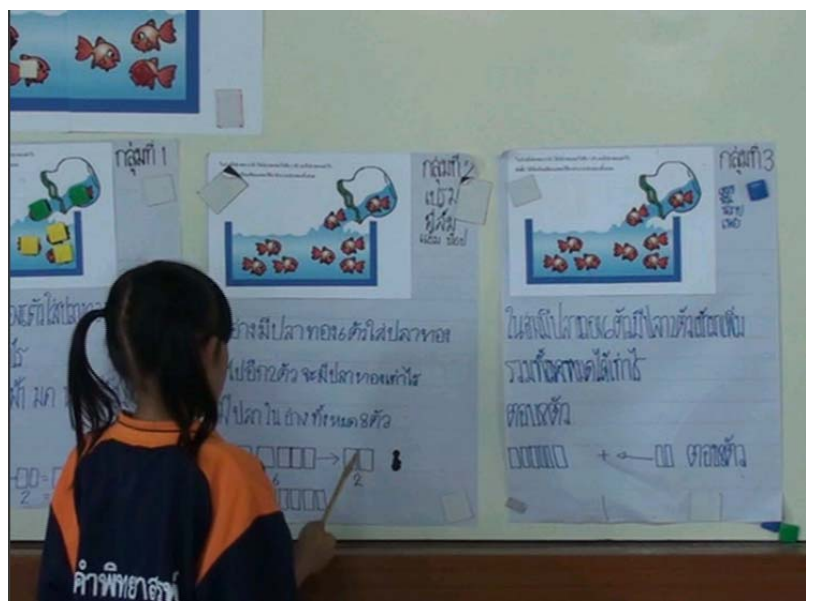

Figure 7.

Students explained their work and reasons in whole class.

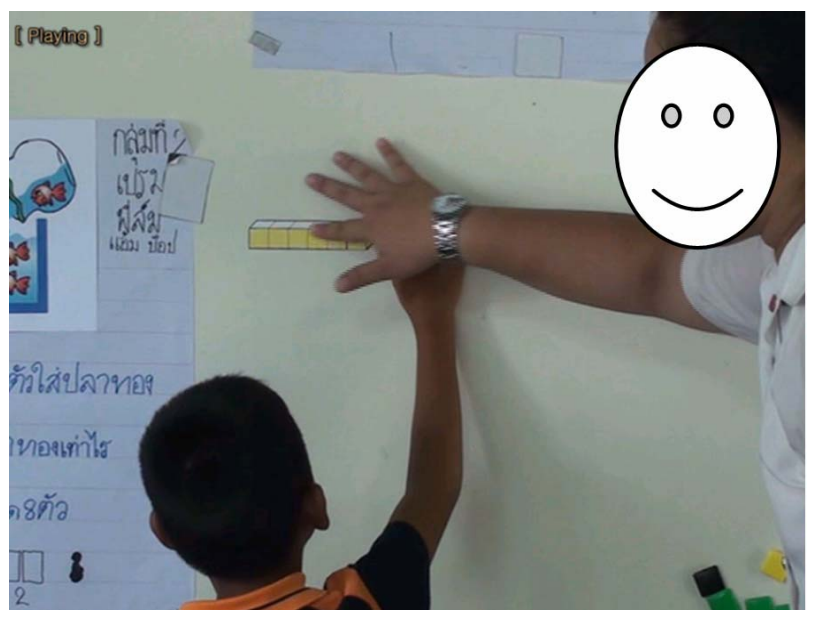

Figure 8.

Students explained their work and reasons in whole class.

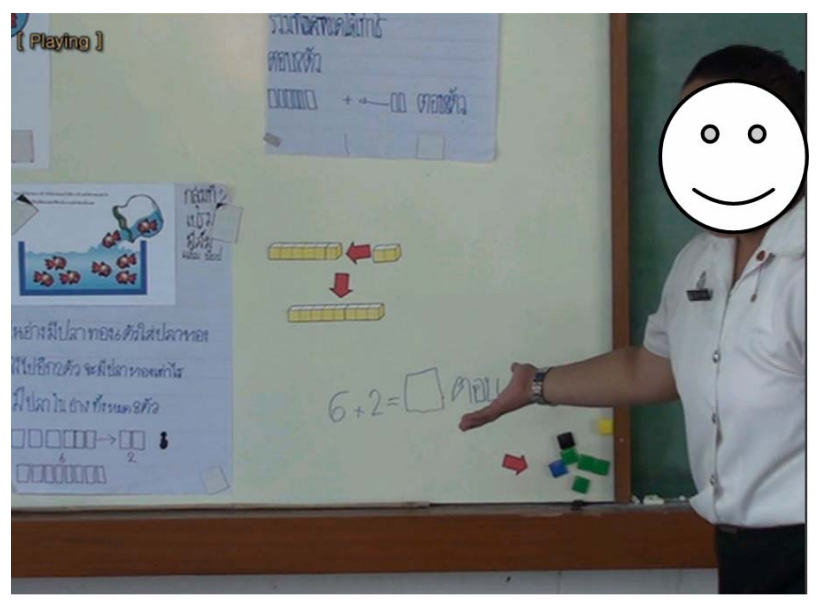

Figure 9.

Discussing the techniques used by students.

3) discuss the wordings or techniques used by students.

\section{Conclusion and Discussion}

Open Approach and Lesson Study support teachers in assessing students' learning by: listening to how students describe their work, using open ended questions for students to explore their ideas, setting problem situation, asking students to communicate their learning through drawings, actions, diagrams, writing and discussing words and how they are used. Inprasitha (2013) stated that an instructional activity based on Open Approach illustrating "how to" assessed students' mathematical learning processes as follows: 1) observing, 2) journals, 3) gathering and arranging information and valuing students' idea, student's solution and also prioritizing students' presentations, 4) questioning, 5) setting tasks, 6) their learning drawing, action, role play, concept mapping as well as writing.

\section{Acknowledgements}

This work was supported by the Higher Education Research Promotion and National Research University Project of Thailand, Office of the Higher Education Commission, through the Cluster of Research to Enhance the Quality of Basic Education and Center for Research in Mathematics Education, Faculty of Education, Khon Kaen University.

\section{REFERENCES}

Black, P., Harrison, C., Lee, C., Marshall, B., \& Wiliam, D. (2004). Working inside the black box: Assessment for learning in the classroom. Phi Delta Kappan, 86, 8-21.

Black, P., \& Wiliam, D. (1998). Assessment and classroom learning. Assessment in Education, 5, 7-74. http://dx.doi.org/10.1080/0969595980050102

Chiengkoon, W. (2006). A report of Thai Education situation 2004/ 2005. The root of the problem and guideline for solving.

Hitotsumatsu, S., et al. (2005). Mathematics for elementary school, $1^{\text {st }}$ grade: Study with your friends. Tokyo: Gekkoh Tosho.

Inprasitha, M., et al. (2003). Mathematical learning process reform in school by focusing on mathematical process (pp. 2-3).

Inprasitha, M. (2004). Teaching by using open approach in mathematics classroom of Japan. KKU Journal of Mathematics Education, 1, 3.

Inprasitha, M. (2010). One feature of adaptive lesson study in Thailand: Designing learning unit. In Proceedings of the $45^{\text {th }}$ National Meeting of Mathematics Education (pp. 19-24). Gyeongju: Dongkook University.

Inprasitha, M. (2013). An assessment of students' mathematical learning process using teaching and learning based on open approach. In Proceedings of the $37^{\text {th }}$ Conference of the International Group for the Psychology of Mathematics Education (5).76. Kiel: PME.

Leahy, S., et al. (2005). Classroom assessment: Minute by minute, day by day. Assessment to Promote Learning, 63, 19-24.

Miyauchi, K. (2010). Assessment as a part of teaching. Journal of Japan Society of Mathematics Education, 26-27.

Robinson, G., \& Bartlett. K (1993) Assessment and the evaluation of learning. In R. J. Jensen (Ed.), Research ideas for the classroom: Early childhood mathematics. New York: Macmillan.

White, A. (2007). Assessment in school mathematics. In N. Idris (Ed.), Classroom assessment in mathematics education (pp. 43-58). Kuala Lumpur: McGraw Hill Education. 